\title{
Three Cases of Tuberculosis in the Neck
}

\author{
Ai Kawamoto, Masaki Ogura and Yukio Katori
}

\begin{abstract}
We report herein on three cases of tuberculosis in the neck region experienced during a recent 1year period. Two cases started with lymphadenopathy and the other started with subcutaneous abscess. Examinations and diagnosis for the tuberculosis were delayed for several weeks, because neither respiratory symptoms nor past and family histories for the tuberculosis were seen in any of the cases. In the examinations to make a diagnosis of tuberculosis, QuantiFERON ${ }^{\circledR}$ TB-2G (QFT) was effective in all three cases. After the diagnosis, all cases were treated with combination chemotherapy of four antituberculosis drugs and the clinical symptoms gradually decreased. Bearing tuberculosis in mind is important in patients with extended lymphadenopathy and infectious regions in the neck.
\end{abstract}

Keywords : tuberculosis, QuantiFERON ${ }^{\circledR}$ TB-2G, extrapulmonary tuberculosis, tuberculous lymphadenitis

\section{References}

1）財団法人結核予防会：結核の統計 2009.1-22，54 頁，財団 法人結核予防会, 東京, 2009 .

2）舘田 勝, 工藤貴之, 長谷川純, 他：頸部結核性リンパ節 炎の確定診断・治療とその問題点. 日耳鼻会報 110：453460, 2007.

3）下出久雄, 村田嘉彦, 草島健二, 他 : 地域病院における肺 外結核症の実態. 結核 69: 519-525, 1994.

4）上田哲也, 村山尚子, 長谷川吉則, 他 : リンパ節結核 23 症 例の臨床的検討．結核 79: 349-354, 2004.

5）青木正和：肺外結核。臨と研 84：542-545, 2007.
6）雑賀太郎，兵 行義，原田 保：頸部結核性リンパ節炎に ついての検討. 日耳鼻感染症研会誌 27: 31-34, 2009.

7) Cantrell RW, Jensen JH and Reid D : Diagnosis and management of tuberculous cervical adenitis. Arch Otolaryngol 101: 53-57, 1975 .

8）佐々木優子, 枝松秀雄, 渋谷和俊 : 頸部結核性リンパ節炎 5 症例の検討. 日耳鼻感染症研会誌 27：35-37, 2009.

9）日本結核病学会予防委員会 : クォンティフェロン ${ }^{\circledR} \mathrm{TB}-2 \mathrm{G}$ の使用指針. 結核 81：393-397, 2006.

10）田中栄治, 森田圭介, 飯坂正義, 他：腹部結核の 2 例：診 断における QuantiFERON ${ }^{\circledR} \mathrm{TB}-2 \mathrm{G}$ の有用性. 日消外会誌 42: 1442-1447, 2009. 

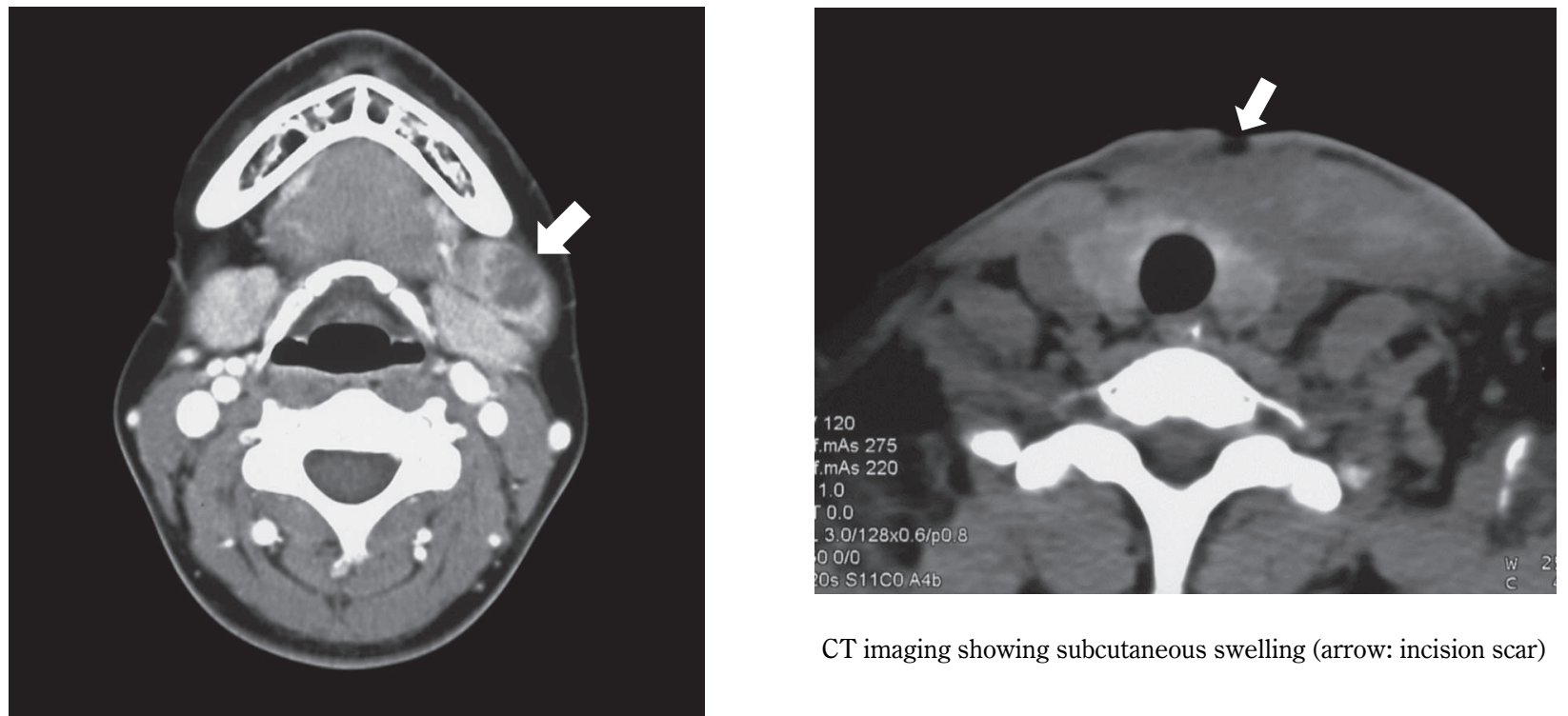

CT imaging showing subcutaneous swelling (arrow: incision scar)

CT scan showing a ring-enhanced lymph node (arrow)

Laboratory data

\begin{tabular}{c|c|c|c|c|c|c|c}
\hline \hline Case & Pathology & Smear & Culture & PCR & QFT & Cytology & Lung disease \\
\hline 1 & + & - & - & + & + & Calss I & - \\
\hline 2 & + & - & - & NA & + & NA & - \\
\hline 3 & NA & + & + & + & + & NA & +
\end{tabular}

PCR, polymerase chain reaction; QFT, QuantiFERON; NA, not available 